\title{
EDUCATION OF PUPILS WITH VISUAL IMPAIRMENT AND THEIR QUALITY OF LIFE
}

\author{
Dita Finková \\ Libuše Ludíková
}

\begin{abstract}
From today's perspective, the right of persons with disabilities to education is considered as standard in developed countries. Each individual can be considered a unique personality, notwithstanding persons with visual impairment. Based on their uniqueness and individuality, each personality is different with regards to their needs from the perspective of education. For persons with visual impairment, we have to consider the scope of education, opt for adequate approaches, forms, etc. Heftiness of caring for such individual is very high, furthermore the subsequent possibilities for development of such persons with respect to future job possibilities are limited. In the Czech Republic, the issue of education and especially equal approach to education is included within statutory standards. In the Czech Republic, meeting the obligation of practical compliance of legislative changes took place relatively quickly, the issue being supervision, including feedback and whether the established concept, together with the change in curriculum, brought improvement in the quality of training pupils with visual impairment. The main issue is whether pupils with special needs leave primary school with such competencies that correspond to the contents defined in the Framework Educational Programme for Primary Schools. Many years have passed since the concept of educating pupils with special needs was introduced, but no studies identifying the level of readiness in primary education graduates who fall under the category of persons with visual impairment have yet been carried out. Owing to the great scope of the given issue, investigation of given competencies cannot be carried out within a short period of time, we have therefore only focused on certain areas, the results of which we would like to present.
\end{abstract}

\section{Keywords}

Visual impairment, quality of education, output competences, curriculum in education.

\section{GROUNDWORK MATERIAL OF THE ISSUE}

In compliance with education of primary school pupils, including pupils with visual impairment, certain important documents need to be followed when conceiving teaching curricula in the Czech Republic. One of the foremost is the 
document Frame Educational Programme for Primary Education, which stems from legislative determinations. What needs to be respected is the momentous position of this document within the system of curricular documents. New principles of curricular policy were formulated in the National Programme of Education Development in the Czech Republic (so-called White Paper) and anchored in Act. No. 561/2004 of Coll. of pre-school, primary, secondary, higher professional and other education (school law) for education of pupils between 3 and 19 years. In real terms, curricular documents are created on two levels - the national one and the school-related one.

The national level in the system of curricular documents is represented by the National Programme of Education and Frame Educational Programmes (RVP). Initial education as a whole is determined in the National programme for education. Frame of educational programmes then define binding frames of education for individual phases (pre-school, primary and secondary education). The school-related level is characterized by school education programmes (ŠVP), based on which the education in individual schools is subsequently carried out (Framework Education Programme for Basic Education, 2007).

Tab. 1: System of curricular documents

\begin{tabular}{|c|c|c|c|c|}
\hline \multirow{4}{*}{ National level } & \multicolumn{4}{|c|}{ National Programme for Education } \\
\hline & \multicolumn{4}{|c|}{ Frame educational programmes } \\
\hline & \multirow{2}{*}{ RVP PV } & \multirow{2}{*}{$\begin{array}{l}\text { RVP ZV } \\
\text { RVP-ZV-LM) }\end{array}$} & $\overrightarrow{R V P ~ G V}$ & \multirow{2}{*}{ other RVP } \\
\hline & & & & \\
\hline School level & School ec & onal programm & & \\
\hline
\end{tabular}

RVP PV - Framework Education Programme for Preschool Education; RVP ZV - Framework Educational Programme for Basic (i.e. primary and lower secondary) Education and Framework Education Programme for Basic Education - Annex Specifying the Education of Pupils with Mild Mental Disabilities (RVP ZV-LMP); RVP GV - Framework Education Programme for Secondary General Education (Grammar Schools); RVP SOV - Framework of Educational Programmes for Secondary Professional Education. Other RVP - Framework of Education Programmes, which are, apart from the abovementioned, directed by the school law - Framework of Education Programme for Basic Art Education, Framework of Education Programme for Language Education, or others.

It follows from this document that teachers were given the chance to create their own educational programmes based on certain particular ideas and experience with teaching in the given school. Without a need for a further approval procedure, it is thus possible to form a compact School Educational Programme (ŠVP) for primary education taking into account experience of teachers and 
needs of pupils. This way, teachers are not restricted to applying exclusively the traditional curriculum as it has been the case in the past. Namely, a teacher does not describe in the plan which "subject matter" is supposed to be presented but which "skills" the students should have. This gives the teacher the option to skip or reduce certain less important passages, whereas some issues, essential and beneficial in the eyes of the teacher, can be studied in more detail. This process is, naturally, carried out with respect to the documents of the higher level.

In line with the change of the documents, all schools in the Czech Republic were obliged to prepare, till commencement of the 2007/2008 school year, their school educational programme ( $\breve{S} V P$ ) and to start applying instructions in this document in classes 1 up to 6, effective of 1.9. 2007.

As far as the principal changes brought about by these documents are concerned, this educational policy, unlike traditional curricula, accentuates "key competencies" and their cohesion with the educational contents as well as application of the acquired skills and knowledge in the real life. RVP formulates the expected level of education for a given phase of the educational process and forms basis for effective and complex application of acquired skills and abilities at the level of key competencies (Framework Education Programme for Basic Education, 2007).

Key competencies are a summary of knowledge, skills, abilities, approaches and values, which play an irreplaceable role for one's personal development and one's application as a member of a society. Their selection and concept derive from generally accepted values within the society and from generally shared ideas about which competencies contribute to one's education, satisfactory and successful life and to strengthening functions as a member of a civil society.

The meaning and objective of education is to equip all pupils with a set of key competencies at a level, which is achievable for them, and thus prepare them for further education and application in the society. Mastering key competencies is a long-term and complex process, which originates in the pre-school education, continues through the primary and secondary education and is gradually accomplished in the course of life. The level of key competencies achievable for pupils at the end of the primary education cannot be regarded as final; the acquired set of skills forms, nevertheless, the basis for the pupil's life-long learning, entry to life and to working experience. Key competencies do not stand isolated; they intertwine in various ways, fulfil multifunctional roles, have interdisciplinary characters and can be, in all cases, acquired only as a result of a complex educational process. That is why the entire educational contents and all school activities must lead up and contribute to their formation and development.

In the educational content of RVP ZV, subject matter is understood as an instrument to mastering activity-based expected outputs, which are gradually interlinked till they create prerequisites for effective and complex application of acquired skills and abilities at the level of key competencies. 
At the stage of primary education, among key competencies count the following: learning competency, competency to solve problems, communicative competency, social and personal competency; civil competencies and work-related competencies (Framework education programme for basic education, 2007).

Educational content of basic education is in RVP ZV divided into 9 educational spheres, where each of them contains one or more related educational objects, as follows below:

- Language and Linguistic Communication (Czech language and literature, foreign language).

- Mathematics and Its Application (Mathematics and its application).

"Information and Communication Technologies (Information and communication technologies).

- Man and His World (Man and his world).

"Man and Society (History, Civics).

" Man and Nature (Physics, Chemistry, Natural science, Geography).

- Arts and Culture (Musical education, Arts).

Man and Health (Health education, Physical education).

" Man and Work (Man and work).

Individual educational fields are, in the introduction, defined by characteristics of educational fields, which express position and significance of a particular field in the primary education and determine educational contents of individual subjects within the given field. This section also indicates connection between educational contents of the $1^{\text {st }}$ and $2^{\text {nd }}$ levels of the primary education. Characteristics are then followed by Targeted Orientation of the Educational Field. This part specifies the objective to be achieved by a pupil through the educational contents in order to gradually master key competencies.

The educational contents of individual educational fields are formed by expected outputs and subject matter. Within the framework of the $1^{\text {st }}$ level, educational contents are further divided into $1^{\text {st }}$ period ( $1^{\text {st }}$ up to $3^{\text {rd }}$ year $)$ and $2^{\text {nd }}$ period ( $4^{\text {th }}$ up to $5^{\text {th }}$ year). Expected outputs have activity-related character, are practical and applicable in everyday life and can be easily verified. They define assumed capability to apply mastered subject matter in practical situations and in real life. RVP ZV defines expected outputs at the end of the $3^{\text {rd }}$ defines expected outputs at the end of the $3^{\text {rd }}$ year ( $1^{\text {st }}$ period) as approximate (non-binding) and at the end of the $5^{\text {th }}$ year $\left(2^{\text {nd }}\right.$ period $)$ and the $9^{\text {th }}$ year as binding.

Subject matter is in RVP ZV structured in individual theme groups (topics, activities) and is understood as an instrument to achieve expected outputs. Due to its informative and formative functions subject matter is an essential part of the educational contents. Subject matter, as defined in RVP ZV, is recommen- 
ded to schools for distribution and further elaboration into individual school years or longer periods of time. At the ŠVP level, subject matter becomes obligatory.

Contents of individual educational branches shall be divided by the school into particular subjects and further elaborated or, if need be, accomplished based on pupils' needs, interests, focus and talent so that the entire teaching concept leads to developing key competencies. In the event that the character of the health impairment, in an objective way, inhibits fulfilling any of the expected outputs in RVP ZV, it is possible, in SVP, to substitute expected outputs with such outputs, which suit better the educational potential of pupils with health impairment. (Framework Education Programme for Basic Education, 2007).

Within the framework of the research of GAČR (Czech Science Foundation) we focused on an educational field Language and linguistic communication and Mathematics and its application. We aim at dwelling on Language and Linguistic Communication in more detail.

\section{FULFILLING KEY COMPETENCIES THROUGH EDUCATIONAL FIELD "LANGUAGE AND LINGUISTIC COMMUNICATION"}

\subsection{Characteristics of the educational field}

In brief, language classes equip pupils with such knowledge and skills, which allow them to perceive correctly various messages, to understand them, express themselves in an adequate way, and to effectively apply as well as enforce results of their cognition.

\subsection{Content of the educational field "Language and Linguistic Education"}

Linguistic education is materialized in the following subjects:

" Czech language and literature,

" foreign language,

" another foreign language.

\section{Educational content of the subject "Czech Language and Literature"}

Content of this educational subject has a complex character and is, for better clarity, divided into three components:

" communication and stylistic education,

- linguistic education,

" literature. 
In real classes, however, educational content of individual components is strongly intertwined. In communication and stylistic education, pupils learn to perceive and understand various messages, read for understanding, write in a sophisticated way, speak and decide on the basis of read or heard texts of various types relating to most varied situations, analyse the text and critically evaluate its content. In higher classes, they also learn to assess the formal character of a text and its construction. In linguistic education pupils acquire knowledge and skills necessary for mastering the literary form of Czech language. They learn to recognize and distinguish other forms of the language. Linguistic education leads pupils to precise and logical thinking, which is a fundamental prerequisite for expressing oneself in a clear, unambiguous and intelligible way.

In the course of developing the necessary knowledge and skills, the pupils' general intellectual faculties are applied and enhanced, such as ability to compare various phenomena, their similarities and differences, sort them out by certain criteria and master generalization. Czech language becomes, from the very beginning of the educational process, not only an instrument to acquiring most information but also a subject to be learnt and examined. In literature, pupils get to know, through reading, basic literary forms, learn to recognize their specific features, find out an author's artistic intentions and formulate their own views of the text. They also gain the ability to distinguish between literary fiction and reality. Gradually, they acquire and develop fundamental reader's habits and ability of creative perception, interpretation and reproduction of a literary text. Pupils arrive at such findings and experiences, which can have a strong positive impact on their approach, value hierarchy and which can enrich their spiritual life.

\subsection{Targeted orientation of the educational field "Language and Linguistic Communication"}

Education in the given field is focused on creating and developing key competencies by motivating a pupil to the following, among others:

- Building a positive relation to the pupil's mother tongue and seeing it as a potential source of developing one's own personal and cultural wealth.

- Perceiving and gradual mastering the language as a rich multiform instrument for acquiring and handing over information, for expressing one's needs and experience and for communicating one's views.

" Mastering common rules for interpersonal communication of a given cultural environment.

- Independent acquiring information from various sources and mastering work with linguistic or literary sources and texts of all sorts of themes.

- Gaining self-confidence for presenting information in public and sophisticated utterance as a tool for self-realisation. 
" Individual experiencing verbal work of fiction, sharing reader's experience, developing a positive relation to literature as well as other types of arts based on artistic texts and developing emotional and aesthetical perception.

\section{EXAMINATION WITHIN THE EDUCATIONAL FIELD "LANGUAGE AND LINGUISTIC COMMUNICATION"}

This examination verified reader's and linguistic competencies through prepared tasks to be solved. Here, we drew our attention to the following issues:

" Text understanding.

Understanding a message.

$\rightarrow$ Analysis and evaluation of the text.

\subsection{Exmination process}

Our examination was carried out in primary schools for visually impaired pupils all over the Czech Republic: in Litovel, Opava, Brno, Plzeň and Prague.

Tab. 2: Examination process

\begin{tabular}{|l|l|l|l|l|l||}
\hline \hline Venue & Litovel & Opava & Brno & Plzeň & Praha \\
\hline $\begin{array}{l}\text { Number } \\
\text { of students }\end{array}$ & 7 & 3 & 7 & 4 & 5 \\
\hline
\end{tabular}

Altogether 26 pupils of the $8^{\text {th }}$ and $9^{\text {th }}$ classes took part in the research examination, carried out in 5 primary schools for visually impaired pupils.

Our research examination was conducted on blind pupils and pupils with impaired vision. Their total number was 26 and they studied the $8^{\text {th }}$ and $9^{\text {th }}$ classes. Testing material was always adjusted based on particular requirements from pupils and school (printed in enlarged black font, in Braille font, in electronic format). Principles of visual hygiene were adhered to, including application of special tools, to which the students are accustomed to when reading and working with texts. 


\subsection{Examples of testing tasks for the educational field "Language and Linguistitc Communication"}

\subsubsection{Task - new situation}

Tab. 3: Task example (new situation)

Instructions: Read the text quietly and reply to the questions below the text.

Passengers of Lufthansa who, after arriving at their destination, miss their luggage can now use a new on-line service for luggage search at. Following their arrival, passengers inform the lost luggage office at the airport about the case and then they receive a report on luggage loss with a reference number. Using this number and one's own name, the passenger can check, from home, office or a hotel room, how the search for the luggage proceeds. Inconveniences related to delay or loss of luggage happen to less than 0.4 customers out of 40 million passengers transported by Lufthansa every year. On the top of it, 95 of claimed losses are detected within 5 days.

Underline a correct answer:

1. Passengers of Lufthansa travel by train - airplane - bus.

2. Passengers get the reference number in the plane-at airport - at train station

3. Problems with luggage occur to approx. $10000-160000-50000$ passengers

4. Almost all losses are sorted out within two days - a week - immediately

Prior to solving the task, it was necessary for the pupils to read the text in Czech language and understand the content. Further on, they analysed the content of the text referring to travelling by air with certain airlines and possible relating complications, i.e. inter-disciplinary links were also developed. This task was supposed to motivate the pupil in taking over the role of a passenger and activate communication facilities in a particular situation, which reflects the pupil's communicational or personal competencies. Applying knowledge with the aim to solve a problem was of utmost significance and allowed us to find out the level of mastering the competencies in order to solve a problem.

Tab. 4: Results of the task (new situation)

\begin{tabular}{||l|l|l|l|l|l||}
\hline \hline & $\begin{array}{l}\text { No. of pupils } \\
\text { with 0 cor- } \\
\text { rect answers }\end{array}$ & $\begin{array}{l}\text { No. of pupils } \\
\text { with 1 cor- } \\
\text { rect answers }\end{array}$ & $\begin{array}{l}\text { No. of pupils } \\
\text { with 2 cor- } \\
\text { rect answers }\end{array}$ & $\begin{array}{l}\text { No. of pupils } \\
\text { with 3 cor- } \\
\text { rect answers }\end{array}$ & $\begin{array}{l}\text { No. of pupils } \\
\text { with 4 cor- } \\
\text { rect answers }\end{array}$ \\
\hline Litovel & 2 & & 5 & 1 & 2 \\
\hline Opava & & & & 2 & 3 \\
\hline Brno & 1 & & 1 & 2 & 1 \\
\hline Plzen & & & 1 & 1 & 1 \\
\hline Praha & & 3 & & & \\
\hline
\end{tabular}


This task allowed maximum of 4 correct answers. The above-stated results indicate how many pupils were successful and tackled the task effectively. Out of the total number of 26 pupils, only 7 pupils answered correctly all questions, 11 pupils made 1 mistake ( 3 correct answers), 5 pupils made 2 mistakes ( 2 correct answer) and 3 pupils fail to solve the task completely.

\subsubsection{Task - well-know texts}

Tab. 5: Task example (well-known texts)

Instructions: Read the sentences carefully and line them up in a correct order. Enter the corresponding symbols into the frames below the text.

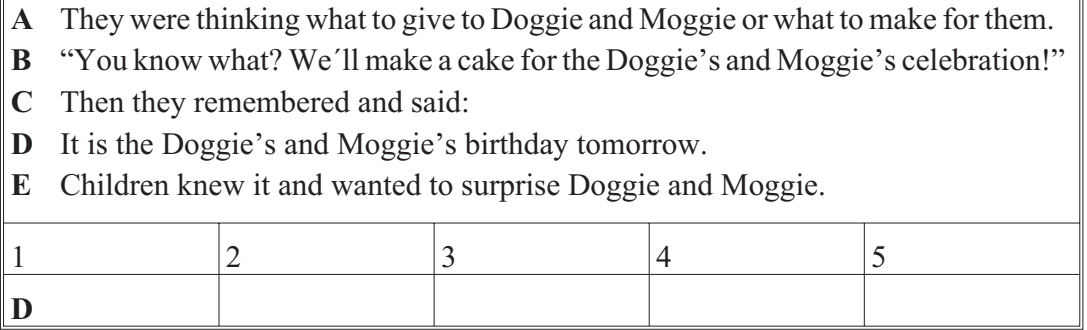

Solving this problem was based on a well-known text by Josef Čapek from the book Povídání o pejskovi a kočičce (The Tales of Doggie and Moggie), which is very popular in the Czech Republic among pre-school children. Primarily, it was important to recall the text which is known to pupils. The task was to line up sentences in a correct order (temporary succession of the text). Pupils had to apply analytic as well as synthetic thinking and to write the result into the pre-prepared table where individual answers were coded with letters. The focus was, marginally, on detecting competencies to solve problems and social competencies, here in a form of relationship to animals. Mastering competencies has a long-term character; here we apply and go back to the initial phase of mastering competencies in the pre-school period.

Tab. 6: Results of the task (well-known texts)

\begin{tabular}{||l|l|l||}
\hline & $\begin{array}{l}\text { Perfect fulfilling of the task } \\
\text { (No. of pupils) }\end{array}$ & $\begin{array}{l}\text { Failing the task } \\
\text { (No. of pupils) }\end{array}$ \\
\hline Litovel & 3 & 4 \\
\hline Opava & 2 & 1 \\
\hline Brno & 5 & 2 \\
\hline Plzen & 4 & - \\
\hline Praha & 2 & 3 \\
\hline
\end{tabular}


The task was fulfilled successfully by 16 pupils out of total 26 . A pupil failed the task even if he/she interchanged only two steps out of total five. Here, it might be suitable, in case of introducing a prime quality evaluation tool, to find out how many steps s pupil mistook and where he/she made the first mistake.

\subsubsection{Task - orientation in a professional text}

Tab. 7: Example of a task (orientation in a professional text)

Instructions: Read carefully the text and answer, in a written form, the questions below.

\section{Characteristics:}

Paracetamol, effective substance of the preparation Paralen 500 tablets counteracts pain and reduces increased body temperature. Tablets Paralen 500 do not aggravate stomach-ache and do not cause emesis. They can be applied by patients with stomach and duodenal ulcers and patient allergic to acetylsalicyl acid.

\section{Dosage and method of application:}

Adults and the youth take $1-2$ tablets of Paralen 500 several times a day, based on the need, in intervals at least 4 hours. The highest individual dosage are 2 tablets, the highest daily dosage are 8 tablets. Patients with reduced function of kidneys use, after consultancy with their G.P., lower dosage. Children between 6 years (or heavier than $20 \mathrm{~kg}$ ) and 15 years use $1 / 2-1$ tablet 3 times a day in intervals at least 6 hours. Tablets Paralen 500 are used while eating, if applied before eating the onset of the effect is faster. Tablets can be cut in half or crushed and should be washed down with a sip of water.

\section{Notice:}

In the event that health troubles (fever, pain) do not recede within 3 days or the difficulties become even worse or unusual reactions occur, consult your G.P. about further application of the preparation.

\section{Warning:}

The preparation may not be applied after the expiry date marked on the packaging. (Source: enclosed pamphlet Paralen ${ }^{\circledR}$ 500, producer: Zentiva a.s., Praha, Czech republic, date of the latest revision:...).

\section{Answer:}

1. When or in which health difficulties is it convenient to apply Paralen?

2. How many (at the most) tablets of Paralen can a 16-year old youth take?

3. You are running a fever. At home in a first-aid kit you find a box of Paralen there the expiration is stated as 15.1.2005. Can you take it?

When solving this task, it was necessary to read, with utmost attention, a professional text dealing with instructions to application of a medicine and divided into several parts. From the task it is obvious that it is necessary to understand the text, to be able to analyse gathered information and to remember it. It was inquired whether a pupil is able to apply acquired competencies in the field of solving a problem and competencies to study. 
Tab. 8: Results of the task (orientation in a professional text)

\begin{tabular}{|l|l|l|l|l||}
\hline & $\begin{array}{l}\text { No. of pupils } \\
\text { who failed } \\
\text { in all the } \\
\text { questions }\end{array}$ & $\begin{array}{l}\text { No. of pupils } \\
\text { with 1 correct } \\
\text { answer }\end{array}$ & $\begin{array}{l}\text { No. of pupils } \\
\text { with 2 correct } \\
\text { answers }\end{array}$ & $\begin{array}{l}\text { No. of pupils } \\
\text { with 3 correct } \\
\text { answers }\end{array}$ \\
\hline Litovel & & & 6 & 1 \\
\hline Opava & & & 3 & \\
\hline Brno & & & 5 & 2 \\
\hline Plzeň & & & 2 & 2 \\
\hline Praha & 1 & & 3 & 1 \\
\hline
\end{tabular}

Only 6 pupils answered all three questions correctly and thus succeeded in this task. 19 pupils made 1 mistake and one pupil failed completely in performing the task.

\section{CONCLUSION}

At the beginning of the study, we asked whether pupils with special needs leave primary schools equipped with such competencies that would correspond with the allotted content of the Frame educational programme for primary schools. As stated above, many years have passed since introducing a new concept (in order to fulfil regulation of the European Union) of educating pupils with special needs but, up till now, there have not been conducted any research investigating the level of preparedness of primary school graduates with visual impairment. With respect to the vast scope of the issue, examination of the given competencies is impossible to be conducted within a short period of time. On top of it, a control tool (mechanism) providing concrete answers is not determined. The principal issue is whether the introduced concept, together with the change of curriculum, has brought about improving the quality of education of pupils with impaired vision. Results of our research examination, whose parts have been presented herein, rather tend to indicate that the given concept does not meet expectations and objectives in full. Then, are ideas and objectives of the European Union absolutely correct in this respect? From the recent monitoring of pupils at various levels over the Czech Republic it follows that the level of knowledge, skills and understanding of pupils within the Czech Republic gradually tends to become worse and worse. So, where does the problem lie? 


\section{List of literature and professional sources}

National Programme for the Development of Education in the Czech Republic. White Paper. Originally published in Czech under the title: Národni program rozvoje vzdéláváni v České republice. Bílá kniha. (2002). Retrieved from http: //aplikace.msmt.cz/pdf/whitepaper.pdf.

Finková, D., Ludíková, L., Růžičková, V. (2007). Special Education of Persons with Visual Disabilities. Originally published in Czech under the title: Speciálni pedagogika osob se zrakovým postižením. Olomouc, CZ: UP.

Finková, D., Růžičková, V., Stejskalová, K. (2010). Introduction to Special Education of Persons with Visual Disabilities. Originally published in Czech under the title: Úvod do speciálni pedagogiky osob se zrakovým postižením. Olomouc, CZ: UP.

Finková, D., Růžičková, V., Stejskalová, K. (2010). Educational Process for People with Visual Disabilities. Originally published in Czech under the title: Edukační proces u osob se zrakovým postižením. Olomouc, CZ: UP.

Framework Education Programme for Basic Education. (2007) Originally published in Czech under the title: Rámcový vzdělávaci program pro základni vzdèlávání. Praha, CZ: Výzkumný ústav pedagogický v Praze. Retrieved from http://www.vuppraha.cz/wp-content/uploads/2009/12/RVPZV_2007-0 7.pdf $>$.

Act No. 561 of $24^{\text {th }}$ September 2004 on pre-school, basic, secondary, tertiary professional and other education (Education Act). Originally published in Czech under the title: Zákon č. 561/2004 o předškolním, základním, středním, vyšším odborném a jiném vzdèlávání (školský zákon).

\section{Contact:}

Mgr. Dita Finková, Ph.D.

Prof. PaedDr. Libuše Ludíková, CSc.

Institute of Special Education Studies

Faculty of Education

Palacký University Olomouc

Žižkovo nám. 5, 77140 Olomouc

Czech Republic

E-mail: ditafinkova@seznam.cz, Phone:+420 585635339

E-mail: libuse.ludikova@upol.cz, Phone: +420 585635001 